\title{
Haem and non-haem iron intake through 17 years of adult life of a British Birth Cohort
}

\author{
J. Johnston ${ }^{1}$, C. J. Prynne ${ }^{1 *}$, A. M. Stephen ${ }^{1}$ and M. E. J. Wadsworth ${ }^{2}$ \\ ${ }^{1}$ MRC Human Nutrition Research, Elsie Widdowson Laboratory, Fulbourn Road, Cambridge CB1 9NL, UK \\ ${ }^{2}$ MRC National Survey of Health and Development, University College and Royal Free Medical School, 1-19 Torrington Place, \\ London WCIE 6BT, UK
}

(Received 3 January 2007 - Revised 29 March 2007 - Accepted 3 April 2007)

An investigation was carried out to determine whether there were significant changes in the intake of haem and non-haem Fe of adult men and women in the UK from 1982 (aged 36 years) to 1999 (aged 53 years). The 1253 subjects studied were members of the Medical Research Council National Survey of Health and Development; a longitudinal study of a nationally representative cohort of births in 1946. Food intake was recorded in a 5-d diary at age 36 years in 1982, 43 years in 1989 and 53 years in 1999. Outcome measures were mean intakes of total Fe, haem and nonhaem $\mathrm{Fe}$, by year, gender and food source. There were significant changes in total $\mathrm{Fe}$, haem $\mathrm{Fe}$ and non-haem $\mathrm{Fe}$ intake over the three time points. Total Fe intake was significantly higher in 1989 than in 1982 or 1999 for both men and women but haem Fe was significantly lower in 1999 mainly due to a $40 \%$ fall in haem Fe from beef during this period. Haem Fe from processed meats fell by more than $50 \%$ between 1989 and 1999 but that from poultry rose by more than $50 \%$. Cereal foods remained the most important source of non-haem Fe and the contribution from breakfast cereals rose relative to that of bread over the 17 years. Several factors could be responsible for these changes, particularly the importance of the epidemic of BSE from 1990. The possible advantages of a lower haem Fe intake in older subjects are discussed.

Haem Fe: Non-haem Fe: Dietary intake

Fe deficiency is one of the most common nutrient deficiencies in the British population, especially amongst pre-menopausal women and children. Measurements of $\mathrm{Fe}$ status in the UK population in 2003 showed that $11 \%$ of women between 19 and 49 years had serum ferritin $<15 \mathrm{ug} / \mathrm{l}$ (the lower limit of the normal range) and $8 \%$ had haemoglobin $<12 \mathrm{~g} / \mathrm{dl}$ (WHO lower limit) ${ }^{1}$. According to the National Food Survey, the overall mean intake of Fe from food sources has fallen from a mean of $14 \mathrm{mg} / \mathrm{d}$ in 1965 to $10 \mathrm{mg} / \mathrm{d}$ in 2000 and the sources of Fe have also changed; reduced consumption of bread and red meat but greater consumption of Fe-fortified breakfast cereals ${ }^{2}$. However, $\mathrm{Fe}$ status is not necessarily related to intake as $\mathrm{Fe}$ absorption depends on bioavailability and the level of $\mathrm{Fe}$ depletion in the body. Non-haem Fe, which makes up $94 \%$ of dietary $\mathrm{Fe}$ in the $\mathrm{UK}^{2}$, is generally less well absorbed than haem $\mathrm{Fe}$ and absorption can be reduced by various factors in the diet, such as tannins, phytates, $\mathrm{Ca}$, polyphenols, soya protein and dietary fibre ${ }^{3}$. The other $6 \%$ of dietary $\mathrm{Fe}$ is haem $\mathrm{Fe}$ that derives mainly from the haemoglobin and myoglobin of meat. Absorption of haem Fe can vary between $40 \%$ during $\mathrm{Fe}$ deficiency to $10 \%$ under conditions of $\mathrm{Fe}$ repletion ${ }^{4}$ and its absorption is less strongly influenced by other dietary factors.
Red meat (beef, lamb and pork) is the main source of haem $\mathrm{Fe}$ and although it still contributes $5 \%$ of total Fe intake ${ }^{2}$, the consumption of red meat has fallen in recent years ${ }^{5}$. Consumption of red meat has been related to the incidence of cancer ${ }^{6}$ and $\mathrm{CVD}^{7}$; the latter attributed largely to the saturated fat content in particular. In addition to these health implications of red meat consumption, the BSE (mad cow disease) epidemic, which reached a peak in 1993, also served to reduce beef consumption in the UK. As a result it would be expected that the proportion of haem $\mathrm{Fe}$ in the diet would be reduced. Although data on haem $\mathrm{Fe}$ intake of British adults have been reported for $2000^{2}$ there is no earlier, nationally representative data to confirm this probable trend. The Medical Research Council National Survey of Health and Development (NSHD) (1946 Birth Cohort) is a longitudinal study that provided the opportunity to examine trends over time in a constant sample of subjects. Results of dietary surveys carried out in 1982, 1989 and 1999 showed that whereas total Fe consumption rose between 1982 and 1989, probably due to increased fortification of some foods, intakes had fallen significantly by 1999 in both men and women ${ }^{8}$. The present paper reports on a re-examination of the dietary data that have separated dietary Fe into haem and nonhaem components and identified changes in the sources of these components. 


\section{Method}

The Medical Research Council NSHD, also known as the 1946 British Birth Cohort, is a longitudinal study of health based on a social class-stratified, random sample of 5362 singleton births in England, Scotland and Wales during the first week of March 1946. Throughout childhood and adult life, medical, social, educational and other information has been collected on twenty-one occasions. Research nurses made home visits at ages 36, 43 and 53 years, in 1982, 1989 and 1999 respectively and left diet diaries to be completed. The population interviewed at the age of 53 years was, in most respects, still representative of a 53-year-old, native-born population ${ }^{9}$. Of the 3035 cohort members who were contacted in 1999, there were 1263 individuals who had also provided dietary data in 1982 and 1989. Of these, there were 1253 subjects; 562 men and 691 women, for whom there were diet records of at least $3 \mathrm{~d}$ collected at each time point. This subsample forms the population for the current analysis.

\section{Dietary assessment}

Details of the subjects and the dietary assessment methods have been reported previously ${ }^{8}$. Subjects were asked to record all food and drink consumed both at home and away in 5-d diaries using household measures and estimated portion sizes according to detailed guidance notes and photographs provided at the beginning of the diary. The diaries were coded using the in-house program DIDO ${ }^{10}$. The coded records were analysed using the in-house analysis program that allows foods to be grouped as required for the purpose of identifying sources of particular nutrients. The in-house food composition database is based on McCance and Widdowson data from 1978 to $2002^{11-16}$ so that each survey was analysed using time-appropriate total $\mathrm{Fe}$ data. Values for haem Fe content were derived from the nutrient databank originally compiled by the Ministry of Agriculture, Fisheries and Food, in which the haem Fe had been calculated as $40 \%$ meat $\mathrm{Fe}^{17}$. The nutrient databank was downloaded from the National Data Archive. The haem Fe content was then adjusted, if necessary, for the total $\mathrm{Fe}$ if that was different in the older database ${ }^{14}$. Recipes were used for calculation of haem and non-haem in foods not on the National Diet and Nutrition Survey (NDNS) database and these calculated values were added to the in-house database.

All foods and drink were separated into groups of haem and non-haem Fe sources. The sources of haem Fe were further subdivided into different types of meat: beef; lamb; pork; poultry; processed meats derived from these. Included in the designation of other meats were fish, offal and game. Nonhaem sources were divided into meat and meat products, fruit, vegetables and potatoes, cereals and cereal products, milk and dairy products, eggs and fats, drinks, confectionery, sauces and soups. Fe from supplements was not included in the analysis.

\section{Statistical analysis}

Data analysis was by SPSS for MS Windows 10 (SPSS Inc., Chicago, IL, USA). Means and $95 \%$ CI for total Fe, haem and non-haem $\mathrm{Fe}$ intakes were calculated at each time point stratified by gender. General linear models, repeated measures, was used to identify significant changes over the 3 years, with post hoc Bonferroni comparisons ${ }^{18}$. Percentage contributions to total haem and non-haem Fe from food groups in 1982 and 1999 were compared and significant differences between the years were identified using the paired sample $t$ test, significance taken as $P<0 \cdot 05$.

\section{Results}

Results are from the population of 1253 individuals, from whom there were dietary records of at least $3 \mathrm{~d}$ collected in 1982 at age 36 years, in 1989 at age 43 years and in 1999 at age 53 years. Five completed days were obtained from $85 \%$ of respondents in $1982,94 \%$ in 1989 and $99.5 \%$ in 1999. Dietary data were analysed according to gender and year of data collection.

Tables 1 and 2 show the mean total Fe, haem and non-haem $\mathrm{Fe}$ intake of men and women respectively in each of the 3 survey years. Also shown are the haem and non-haem $\mathrm{Fe}$ intakes from each of the dietary sources. There was a significant increase in total $\mathrm{Fe}$ intake from 1982 to 1989 due to an increase in non-haem $\mathrm{Fe}$ intakes in both men and women. There were significant decreases in mean total $\mathrm{Fe}$ intakes in 1999 compared to 1989 in both men and women, but intakes from women did not fall below that in 1982. However, haem Fe intakes in 1999 were significantly lower than those in 1989 and 1982 for men and women. The percentage of total Fe that was haem Fe fell from 9 to 6 in men and 8 to 5 in women.

Haem $\mathrm{Fe}$ from beef and pork remained constant between 1982 and 1989 but fell significantly in 1999 in both men and women. Haem Fe from lamb fell significantly from 1982 to 1989 in men and continued to fall between 1989 and 1999 in women, while that from poultry rose continuously and significantly from 1982 to 1999 in all subjects.

Of other haem Fe sources, the quantity from processed meats fell significantly in 1999 to less than half the intake in 1989. Offal is a very rich source of Fe but the quantity of haem Fe from this source was halved between 1982 and 1999.

Intakes of non-haem Fe from cereal foods increased significantly between 1982 and 1989 in men and women and fell again in 1999 but not below the 1982 level. The intake of non-haem $\mathrm{Fe}$ from breakfast cereals, in particular, nearly doubled between 1982 and 1989 in men and was also significantly higher in women. There was no significant change in the intake of non-haem Fe from this source between 1989 and 1999 but the intake from bread fell significantly in all subjects during this period.

Non-haem Fe from meat, fish, and dishes containing meat or fish fell from 1982 to 1999 in both men and women. However, that from fruit and vegetables increased from 1982 to 1989 in men and again from 1989 to 1999 in women. Nonhaem Fe from dairy products and eggs declined throughout the years in men and between 1982 and 1989 in women. Other non-haem Fe sources, which include confectionery, sauces, soups and beverages (consisting of alcohol, fizzy drinks, squashes and water), increased from 1989 to 1999. In particular, the $\mathrm{Fe}$ intake from red wine increased significantly $(P<0.001)$; intake in 1999 being more than double that in 1989 (result not shown). 
Table 1. Haem and non-haem Fe intakes of British men, by year of dietary survey and by food source $\dagger$ (Mean values and $95 \% \mathrm{Cl}$ for 562 subjects)

\begin{tabular}{|c|c|c|c|c|c|c|}
\hline \multirow[b]{2}{*}{$\mathrm{Fe}(\mathrm{mg} / \mathrm{d})$} & \multicolumn{2}{|c|}{1982 (36 years) } & \multicolumn{2}{|c|}{1989 (43 years) } & \multicolumn{2}{|c|}{1999 (53 years) } \\
\hline & Mean & $95 \% \mathrm{Cl}$ & Mean & $95 \% \mathrm{Cl}$ & Mean & $95 \% \mathrm{Cl}$ \\
\hline Total Fe & $12 \cdot 99^{a}$ & $12 \cdot 71,13 \cdot 28$ & $13 \cdot 7^{\mathrm{b}}$ & $13 \cdot 37,14 \cdot 10$ & $12 \cdot 7^{\mathrm{a}}$ & $12 \cdot 4,13 \cdot 0$ \\
\hline Haem Fe & $1 \cdot 17^{\mathrm{a}}$ & $1 \cdot 12,1 \cdot 26$ & $1 \cdot 12^{\mathrm{a}}$ & $1.06,1 \cdot 18$ & $0 \cdot 78^{b}$ & $0.73,0.83$ \\
\hline Non-haem Fe & $11 \cdot 83^{\mathrm{a}}$ & $11.56,12.09$ & $12 \cdot 61^{\mathrm{b}}$ & $12 \cdot 27,12 \cdot 96$ & $11 \cdot 88^{\mathrm{a}}$ & $11 \cdot 6,12 \cdot 16$ \\
\hline \multicolumn{7}{|l|}{ Haem Fe sources } \\
\hline Beef & $0.47^{\mathrm{a}}$ & $0.44,0.49$ & $0.48^{a}$ & $0.45,0.51$ & $0.28^{b}$ & $0.26,0.30$ \\
\hline Lamb & $0 \cdot 13^{\mathrm{a}}$ & $0 \cdot 10,0.15$ & $0.07^{\mathrm{b}}$ & $0.06,0.09$ & $0.06^{\mathrm{b}}$ & $0.05,0.07$ \\
\hline Pork & $0.23^{a}$ & $0.22,0.25$ & $0.23^{a}$ & $0.21,0.25$ & $0.14^{\mathrm{b}}$ & $0.13,0.15$ \\
\hline Poultry & $0.06^{\mathrm{a}}$ & $0.05,0.07$ & $0.07^{\mathrm{b}}$ & $0.07,0.08$ & $0.11^{\mathrm{c}}$ & $0.1,0.12$ \\
\hline Of which: processed meats & $0.38^{a}$ & $0.35,0.40$ & $0.36^{a}$ & $0.33,0.4$ & $0.17^{\mathrm{b}}$ & $0.16,0.19$ \\
\hline Other haem Fe sources & 0.28 & $0.24,0.32$ & 0.26 & $0.22,0.30$ & 0.19 & $0.15,0.23$ \\
\hline Of which: Fish & 0.06 & $0.05,0.07$ & 0.09 & $0.07,0.11$ & 0.09 & $0.06,0.11$ \\
\hline Offal & $0.22^{\mathrm{a}}$ & $0.18,0.25$ & $0.17^{\mathrm{a}}$ & $0.14,0.20$ & $0.10^{\mathrm{b}}$ & $0.07,0.13$ \\
\hline Game & 0.01 & $0.00,0.01$ & 0.01 & $0.00,0.01$ & 0.00 & $0.00,0.01$ \\
\hline \multicolumn{7}{|l|}{ Non-haem Fe sources } \\
\hline Total cereal foods & $4.94^{\mathrm{a}}$ & $4.58,5.29$ & $5.78^{\mathrm{b}}$ & $5 \cdot 35,6 \cdot 22$ & $5 \cdot 13^{\mathrm{a}}$ & $4.76,5.49$ \\
\hline Of which: Breakfast cereals & $0.93^{\mathrm{a}}$ & $0.79,1.08$ & $1.79^{\mathrm{b}}$ & $1.56,2.02$ & $1.71^{\mathrm{b}}$ & $1.54,1.88$ \\
\hline Bread & $2 \cdot 64^{\mathrm{a}}$ & $2.53,2.75$ & $2 \cdot 73^{a}$ & $2 \cdot 62,2 \cdot 84$ & $2 \cdot 29^{b}$ & $2 \cdot 2,2 \cdot 38$ \\
\hline Cakes, biscuits, puddings & $1 \cdot 23^{\mathrm{a}}$ & $1 \cdot 16,1 \cdot 31$ & $1 \cdot 11^{\mathrm{a}}$ & $1.04,1.18$ & $0.77^{\mathrm{b}}$ & $0.71,0.82$ \\
\hline Other cereals & $0 \cdot 13^{\mathrm{a}}$ & $0.11,0.16$ & $0 \cdot 15^{a}$ & $0.13,0.18$ & $0.36^{\mathrm{b}}$ & $0.31,0.41$ \\
\hline Meat, fish (incl. products and dishes) & $2 \cdot 38^{\mathrm{a}}$ & $2 \cdot 30,2.47$ & $2 \cdot 06^{\mathrm{b}}$ & $1 \cdot 96,2 \cdot 16$ & $1 \cdot 75^{\mathrm{c}}$ & $1.66,1.84$ \\
\hline Fruits, nuts, vegetables (incl. potatoes) & $2 \cdot 25^{\mathrm{a}}$ & $2 \cdot 18,2 \cdot 31$ & $2.55^{\mathrm{b}}$ & $2.44,2.66$ & $2 \cdot 52^{\mathrm{b}}$ & $2.43,2.61$ \\
\hline Dairy products and eggs & $0.82^{a}$ & $0.79,0.86$ & $0.75^{\mathrm{b}}$ & $0.71,0.79$ & $0.66^{\mathrm{c}}$ & $0.61,0.71$ \\
\hline Other foods* & $1.38^{a}$ & $1.29,1.47$ & $1.45^{a}$ & $1.32,1.51$ & $1.81^{\mathrm{b}}$ & $1.68,1.94$ \\
\hline
\end{tabular}

${ }^{a, b, c}$ Mean values within a row with unlike superscript letters were significantly different $(P<0.05)$.

* Includes sugars, preserves, confectionery, beverages, sauces and soups.

†For details of subjects and procedures, see Method.

Table 2. Haem and non-haem Fe intakes of British women, by year of dietary survey and by food source $\dagger$ (Mean values and $95 \% \mathrm{Cl}$ for 691 subjects)

\begin{tabular}{|c|c|c|c|c|c|c|}
\hline \multirow[b]{2}{*}{$\mathrm{Fe}(\mathrm{mg} / \mathrm{d})$} & \multicolumn{2}{|c|}{1982 (36 years) } & \multicolumn{2}{|c|}{1989 (43 years) } & \multicolumn{2}{|c|}{1999 (53 years) } \\
\hline & Mean & $95 \% \mathrm{Cl}$ & Mean & $95 \% \mathrm{Cl}$ & Mean & $95 \% \mathrm{Cl}$ \\
\hline Total Fe & $10 \cdot 46^{\mathrm{a}}$ & $10 \cdot 18,10 \cdot 74$ & $11 \cdot 24^{\mathrm{b}}$ & $10 \cdot 97,11 \cdot 51$ & $10 \cdot 80^{\mathrm{a}}$ & $10.58,11.02$ \\
\hline Haem Fe & $0.83^{a}$ & $0.79,0.86$ & $0.78^{\mathrm{a}}$ & $0.75,0.82$ & $0.52^{\mathrm{b}}$ & $0.49,0.55$ \\
\hline Non-haem Fe & $9 \cdot 63^{\mathrm{a}}$ & $9 \cdot 36,9.90$ & $10 \cdot 46^{\mathrm{b}}$ & $10 \cdot 19,10 \cdot 72$ & $10 \cdot 28^{b}$ & $10 \cdot 07,10.48$ \\
\hline \multicolumn{7}{|l|}{ Haem Fe sources } \\
\hline Beef & $0.31^{a}$ & $0.3,0.33$ & $0.32^{\mathrm{a}}$ & $0.30,0.34$ & $0.18^{\mathrm{b}}$ & $0.16,0.19$ \\
\hline Lamb & $0.11^{a}$ & $0.09,0.12$ & $0.07^{b}$ & $0.06,0.08$ & $0.04^{\mathrm{c}}$ & $0.04,0.05$ \\
\hline Pork & $0.16^{a}$ & $0.15,0.17$ & $0.15^{\mathrm{a}}$ & $0.14,0.15$ & $0.09^{b}$ & $0.09,0.1$ \\
\hline Poultry & $0.05^{a}$ & $0.05,0.05$ & $0.06^{b}$ & $0.06,0.06$ & $0.09^{c}$ & $0.08,0.1$ \\
\hline Of which: processed meats & $0.26^{a}$ & $0.24,0.28$ & $0.23^{\mathrm{a}}$ & $0.21,0.25$ & $0.1^{\mathrm{b}}$ & $0.09,0.11$ \\
\hline Other haem Fe sources & $0.2^{\mathrm{a}}$ & $0.17,0.22$ & $0 \cdot 19^{\mathrm{a}}$ & $0.16,0.21$ & $0.11^{\mathrm{b}}$ & $0.09,0.14$ \\
\hline Of which: Fish & 0.05 & $0.04,0.05$ & 0.07 & $0.06,0.08$ & 0.06 & $0.05,0.06$ \\
\hline Offal & $0.14^{\mathrm{a}}$ & $0.12,0.16$ & $0 \cdot 11^{\mathrm{a}}$ & $0.09,0.13$ & $0.05^{\mathrm{b}}$ & $0.03,0.08$ \\
\hline Game & 0.01 & $0.00,0.01$ & 0.01 & $0.00,0.01$ & 0.00 & $0.00,0.01$ \\
\hline \multicolumn{7}{|l|}{ Non-haem Fe sources } \\
\hline Total cereal foods & $4 \cdot 22^{a}$ & $3.98,4.59$ & $4.86^{\mathrm{b}}$ & $4 \cdot 63,5 \cdot 10$ & $4 \cdot 37^{\mathrm{a}}$ & $4 \cdot 22,4.52$ \\
\hline Of which: Breakfast cereals & $1 \cdot 10^{\mathrm{a}}$ & $0.89,1.31$ & $1.74^{\mathrm{b}}$ & $1.54,1.94$ & $1.62^{b}$ & $1.49,1.75$ \\
\hline Bread & $1.88^{\mathrm{a}}$ & $1.81,1.96$ & $2 \cdot 02^{\mathrm{b}}$ & $1 \cdot 94,2 \cdot 10$ & $1.77^{\mathrm{C}}$ & $1.71,1.83$ \\
\hline Cakes, biscuits, puddings & $1 \cdot 10^{\mathrm{a}}$ & $1.05,1.16$ & $0.98^{\mathrm{a}}$ & $0.93,1.03$ & $0.67^{b}$ & $0.63,0.71$ \\
\hline Other cereals & $0.14^{\mathrm{a}}$ & $0.11,0.17$ & $0 \cdot 13^{\mathrm{a}}$ & $0 \cdot 1,0 \cdot 15$ & $0.31^{\mathrm{b}}$ & $0.28,0.34$ \\
\hline Meat, fish (incl. products and dishes) & $1.64^{\mathrm{a}}$ & $1.58,1.70$ & $1.38^{\mathrm{b}}$ & $1.32,1.45$ & $1 \cdot 19^{\mathrm{c}}$ & $1 \cdot 14,1 \cdot 25$ \\
\hline Fruits, nuts, vegetables (incl. potatoes) & $1.72^{\mathrm{a}}$ & $1.67,1.77$ & $2 \cdot 22^{\mathrm{b}}$ & $2 \cdot 16,2 \cdot 29$ & $2.49^{\mathrm{c}}$ & $2.40,2.57$ \\
\hline Dairy products and eggs & $0.71^{\mathrm{a}}$ & $0.69,0.74$ & $0.66^{\mathrm{b}}$ & $0.63,0.69$ & $0.66^{\mathrm{b}}$ & $0.61,0.71$ \\
\hline Other foods* & $1.30^{\mathrm{a}}$ & $1.23,1.37$ & $1.29^{\mathrm{a}}$ & $1.22,1.35$ & $1.56^{\mathrm{b}}$ & $1.47,1.65$ \\
\hline
\end{tabular}

a,b,c Mean values within a row with unlike superscript letters were significantly different $(P<0.05)$.

*Includes sugars, preserves, confectionery, beverages, sauces and soups.

†For details of subjects and procedures, see Method. 
Figs. 1 and 2 show the mean percentage contributions of haem and non-haem Fe from different sources in the diet of these subjects in 1982 and 1999. The most significant change in sources of haem $\mathrm{Fe}$ was the fall in the contribution from beef from $41 \%$ to $35 \%$ (men) and from $40 \%$ to $29 \%$ (women) from 1982 to 1999. Although haem Fe intakes from beef were seen to fall, beef still remained the main contributor of haem Fe. The contribution to haem Fe intakes from lamb was much smaller but also fell significantly between 1982 and 1999. The percentage contribution from poultry in women showed a nearly three-fold increase between 1982 and 1999 and in men increased from $7 \%$ to $18 \%$. The percentage contribution from other sources did not change significantly over the two time points.

Examination of non-haem Fe sources shows that in 1982 the main contributor was bread. In 1999, fruit and vegetables contributed the greatest percentage, the contribution from these foods rose between the years, particularly in women. Cereals and cereal products, which included breakfast cereals, bread, cakes, biscuits and puddings, contributed almost half of the non-haem $\mathrm{Fe}$ intake, ranging from $40-42 \%$ in both survey
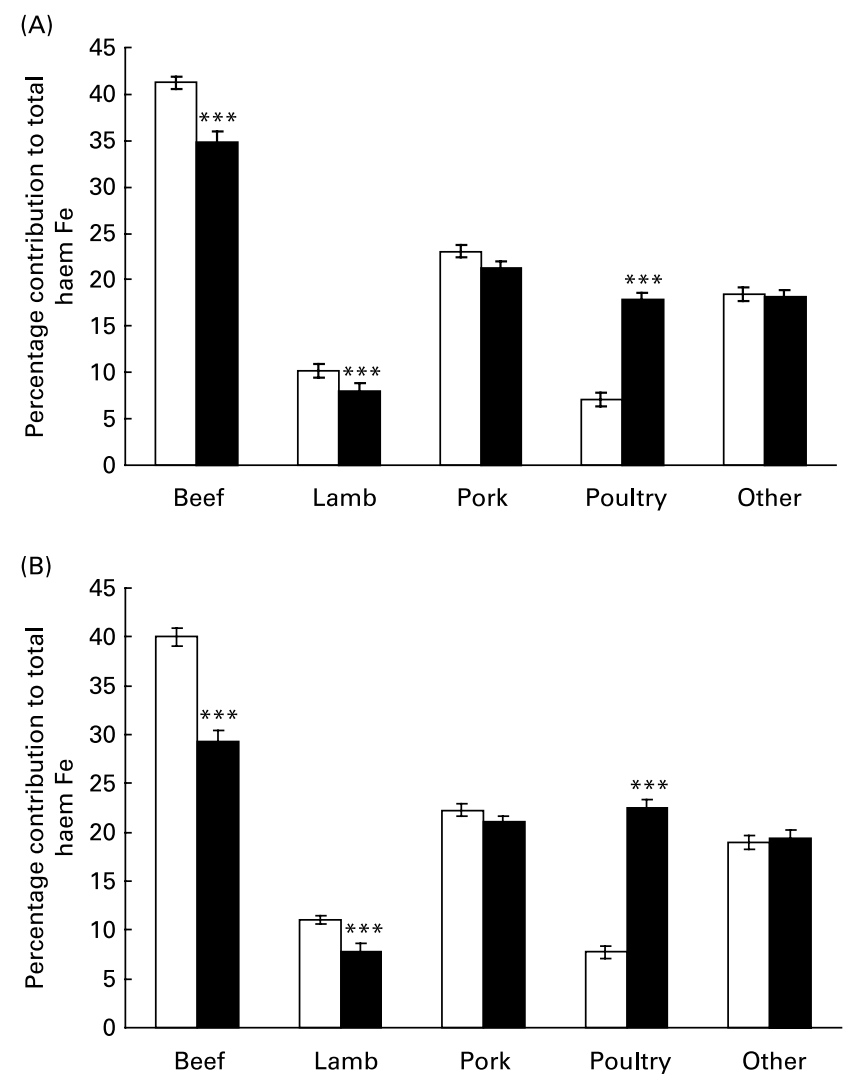

Fig. 1. Mean percentage contribution to total haem Fe intake from different meats by year $(\square, 1982 ; \mathbf{\square}, 1999)$ for $(A)$ men and (B) women. The $Y$ axis shows the mean percentage contribution from each of the types of meat given on the $X$ axis. 'Other' refers to fish, offal and game. The standard errors of the means are indicated by the vertical bars. Food intake data was recorded in a 5-d diary by subjects in the National Survey of Health and Development 1946 birth cohort at three time points: 1982; 1989; 1999. The results shown are for the 562 men and 691 women who completed at least $3 \mathrm{~d}$ of records in all 3 years. Mean values were significantly different from those of 1982: ${ }^{\star \star \star} P<0.001$. For details of subjects and procedures, see Method.
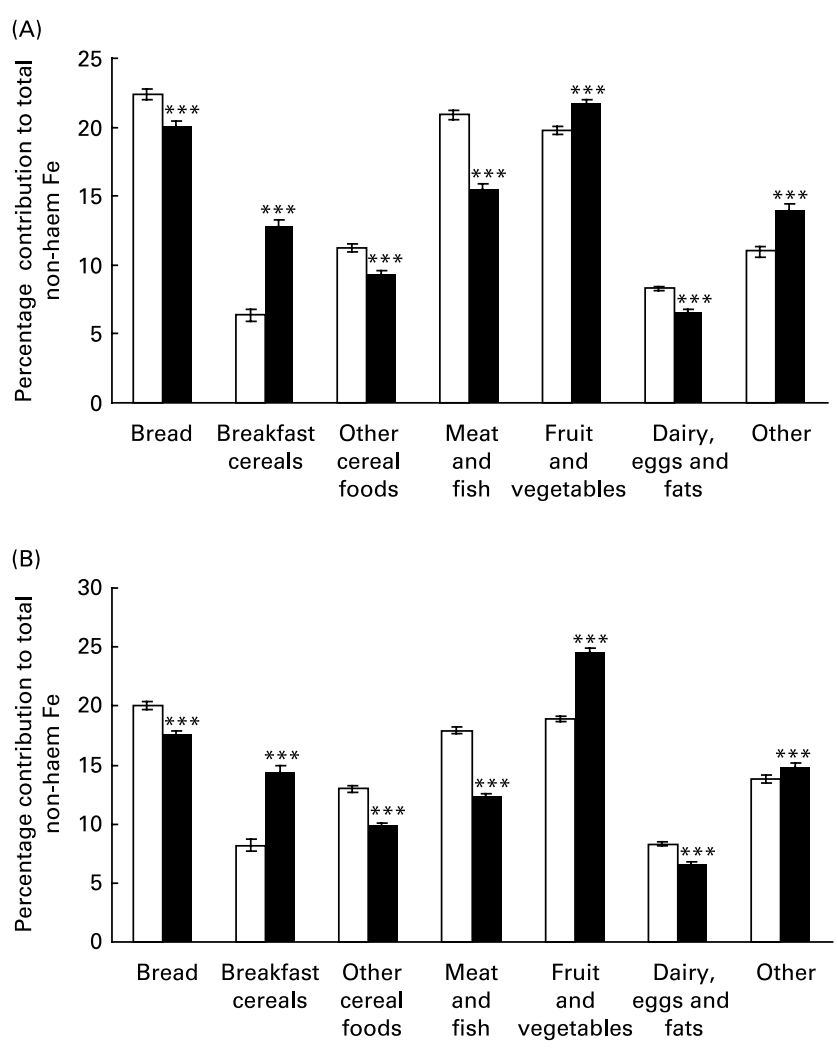

Fig. 2. Mean percentage contribution to total non-haem Fe intake from different food groups by year $(\square, 1982 ; \mathbf{\square}, 1999)$ for (A) men and (B) women. The $Y$ axis shows the mean percentage contribution of food groups given on the $X$ axis. 'Other' refers to sugars, confectionery, sauces, soups and beverages. The standard errors of the means are indicated by the vertical bars. Food intake data was recorded in a 5-d diary by subjects in the National Survey of Health and Development 1946 birth cohort at three time points: 1982; 1989; 1999. The results shown are for the 562 men and 691 women who completed at least $3 \mathrm{~d}$ of records in all 3 years. Mean values were significantly different from those of 1982 : ${ }^{\star \star *} P<0.001$. For details of subjects and procedures, see Method.

years. The greatest change in percentage contribution to non-haem $\mathrm{Fe}$ intake was the increase in that from breakfast cereals, particularly in men where the contribution doubled between 1982 and 1999.

\section{Discussion}

The present study identifies significant changes in the intake of haem and non-haem $\mathrm{Fe}$ in a cohort of adults in the UK investigated over a period of 17 years. Changes in total Fe intake have already been reported with regard to the NSHD 1946 Birth Cohort ${ }^{8}$ but separate intakes of haem and non-haem Fe intakes were not available at the time. The main findings of the present study were:

1. Haem and non-haem Fe intakes rose through the years of 1982 to 1989 and fell in 1999; the same trend as that for total Fe.

2. Of the haem Fe sources, beef and beef products were the main contributors at all time points, followed by poultry, pork and lamb. There was a decline in the intake of haem Fe from beef, paralleled by an increase in that from poultry between 1989 and 1999. 
3. Of non-haem Fe sources, the main contribution was from cereal foods, including breakfast cereals, bread and other cereals such as pasta, rice, cakes, biscuits and puddings, followed by fruit, nuts and vegetables and meat. The contribution from breakfast cereals became relatively more important over the 17 years.

This is the first study to identify changes in haem and nonhaem Fe that have taken place over the critical period of the BSE epidemic in a nationally representative sample. A comparison of beef-eaters and non-beef-eaters of the UK women's cohort study was undertaken to investigate whether $\mathrm{Fe}$ intakes were lower in the non-beef-eaters but this was a cross sectional survey carried out between 1995 and 1996 with no pre-BSE data for comparison, nor was haem Fe separated from non-haem $\mathrm{Fe}^{19}$. The strength of the present study was that the same subjects were investigated at the different time points. However, this results in the subjects being older at each time point and the changes that might be due to ageing cannot be separated from secular changes. A minor weakness of the study is that the number of subjects who completed diaries at all three time points was small. Although 3035 of the original cohort were contacted in 1999, only 1253 had completed food diaries at all time points and these may be the most motivated members of the cohort, with dietary characteristics that may have been different from those who did not complete diaries. The majority of these subjects were from non-manual occupational social classes ${ }^{8}$ who tend to have a greater degree of literacy and are more health aware. Another weakness of the study was the haem $\mathrm{Fe}$ database on which the results were based. The values on the Ministry of Agriculture Fisheries and Food database were calculated on the assumption that $40 \%$ of all meat $\mathrm{Fe}$ was haem Fe. This assumption was, in turn, taken from the work of Monsen, who reported that 30 to $40 \%$ of the $\mathrm{Fe}$ in pork, liver and fish and 50 to $60 \%$ of the $\mathrm{Fe}$ in beef, lamb and chicken was haem $\mathrm{Fe}^{20}$. As these figures come from analyses carried out many years ago, there are grounds for concern that the basis of any work carried out on haem Fe intakes using the Ministry of Agriculture Fisheries and Food databank may be unsound. More recent analyses of meat in Italy have reported $72-87 \%$ haem $\mathrm{Fe}$ in red meats while the haem $\mathrm{Fe}$ of poultry varied markedly between muscles ${ }^{21}$. However, since the same values have been used for the national surveys ${ }^{2,22}$ as for the present study, comparisons would still be valid.

Although we can speculate on the causes of the changes, there have been many different ways in which intakes of haem $\mathrm{Fe}$ or non-haem $\mathrm{Fe}$ could have been influenced during the years that have been studied. The range of foods, particularly convenience foods, available to consumers has changed and expanded. Estimation of the $\mathrm{Fe}$ content of these ready-made meals can be imprecise, as the formulation may differ from similar foods prepared at home from ingredients. In addition, the price of foods, particularly of different types of meat relative to one another, may have had an impact on consumer choice. Another factor is the change in the nutrient content of foods. With regard to meat, this may be due to changes in animal husbandry and slaughtering practices. Animals are now killed at a young age and there is some evidence that intensive rearing results in lower mineral content of meat ${ }^{23}$. Since 1996, unless certified under the Beef Assurance Scheme, cattle must be slaughtered before 30 months of age ${ }^{24}$. With regard to non-haem Fe, levels of food fortification, particularly of breakfast cereals, have also changed over the years ${ }^{11,12,14}$.

Changes in haem Fe intake over time and contribution from different food sources

As beef and beef products were the main contributor to the haem Fe intake in the diets of the subjects at all time points, the decline in beef consumption between 1989 and 1999 was the main cause of the reduction in total haem Fe intake in 1999. BSE was first confirmed in cattle in $1986^{25}$ and was given further impetus by the announcement by the Secretary of State for Health in 1996 that there may be a link between BSE in cattle and variant CJD in man. This resulted in a significant loss of confidence in British beef, especially the cheaper cuts and beef products, both in the UK and in many export markets. Between 1982 and 1996, national consumption of beef and veal was halved and, although there was some recovery in consumption by 1997 , it did not return to pre-BSE levels ${ }^{5}$. Data from the NSHD showed that haem Fe from beef in 1999 was approximately $40 \%$ lower than that of 1982 so the consumption of beef would appear to mirror that reported by the National Food Survey, which reports data derived from household purchases ${ }^{5}$. However, in a comparison of non-beef-eating meat eaters and beef-eating meat eaters in the UK Women's Cohort Study, no difference was found in total Fe intake ${ }^{19}$.

Although BSE is considered to be the major contributory factor to the reduction in beef consumption, there was already a decline in haem $\mathrm{Fe}$ intake between 1982 and 1989. The contribution to haem Fe from lamb also fell through the years in the survey. This mirrors the National Food Survey lamb and mutton consumption figures for 1982, 1989 and $1999^{5}$. The consumption of lamb did not rise in response to the decline in beef consumption in 1999, which could be explained by the cost of lamb relative to beef. In 1989 the cost of lamb was $26 \%$ less than beef but this difference had reduced to $8 \%$ by 1999 . In addition, the public loss of confidence in beef may also have extended to lamb, as there was speculation about the relationship of BSE to scrapie, spongiform encephalopathy of sheep ${ }^{26}$. The rise in haem Fe from poultry is a direct consequence of the fall in that from beef. The consumption of lean poultry has been encouraged to reduce the intake of saturated fats and, together with the health scare engendered by BSE, this has resulted in an increase in poultry consumption coincident with the move away from red meats ${ }^{8}$. The fall in haem $\mathrm{Fe}$ from processed meats between 1989 and 1999 may have been due to reduced consumption of processed meats as the public became more aware of the risks to health that consumption of processed meats presented, such as colorectal cancer ${ }^{27}$. There was also concern that processed beef products, particularly those made from mechanically recovered meat, could be contaminated with parts of the cow that were infected with BSE. In 1999 the NSHD cohort were at an age when the maintenance of good health was becoming of greater significance so their response to all the factors described earlier might have 
been greater than that of younger people. Comparison with a nationally representative sample of the same age shows that total haem Fe intake of the 1946 cohort in 1999 was only slightly lower than that reported by the NDNS for the 50-64 year old age group in 2001 (0.78 compared with $0.9 \mathrm{mg} / \mathrm{d}$ (men); 0.52 compared with $0.6 \mathrm{mg} / \mathrm{d}$ (women) ${ }^{2}$.

\section{Changes in non-haem Fe intake over time and contribution from other sources}

In agreement with the findings of the 2001 NDNS, over $90 \%$ of the total Fe intake in this survey was in the form of nonhaem Fe. Of this, bread and breakfast cereals provided $33 \%$, which is slightly lower than that reported by the NDNS $(35 \%$ men and $37 \%$ women $)^{2}$. The contribution from breakfast cereals increased through the years 1982 to 1989, when there were substantial increases in Fe fortification levels ${ }^{11,12,14}$, in addition to an increase in the quantity of breakfast cereals consumed (results not shown). A total of $73 \%$ of the increase in Fe intake between 1982 and 1989 was due to fortification. Fruit and vegetable contribution to non-haem Fe increased in both men and women, although the increase was greater in women. A rise in the consumption of fruit and vegetables, particularly in the women of this cohort, has already been reported and has been attributed to the exposure to health messages in the media as well as advice from health professionals and the government ${ }^{8}$.

The present results have shown that the intake of haem $\mathrm{Fe}$ as a percentage of total Fe intake has fallen as predicted in this cohort over a period of 17 years and this probably reflects the national situation, as the 1999 NSHD results closely mirror those of the NDNS 2001: 0.9 and $0.6 \mathrm{mg} / \mathrm{d}$ for men and women respectively in the 50-64 year age group ${ }^{2}$. The estimated average haem Fe intake in the UK in 1977 was $1.29 \mathrm{mg} / \mathrm{d} ; 13 \%$ total Fe from food sources ${ }^{22}$, which is higher than the intake of the NSHD men in 1982. As absorption of haem Fe is known to be better than that of non-haem Fe and less affected by other dietary constituents, this reduction in intake over the years could be cause for concern if the same intakes were found in younger women in the UK. If this was the case, $16 \%$ would have Fe intakes lower than the Lower Reference Nutrient Intake (LRNI), of which only $5 \%$ would be of the more available haem $\mathrm{Fe}^{28}$. However, the majority of the women of the NSHD cohort would have been post-menopausal in 1999 and their $\mathrm{Fe}$ requirement considerably reduced; from $14.8 \mathrm{mg} / \mathrm{d}$ (pre-menopause) to $8.7 \mathrm{mg} / \mathrm{d}^{28}$.

The relationship between haem $\mathrm{Fe}$ intake and $\mathrm{Fe}$ accumulation in the body remains controversial. Garry et al. found no association between dietary haem Fe intake and Fe stores in either a longitudinal or cross sectional study of elderly men and women, aged from 60 to 93 years $^{29}$. However, analysis of the data from the NDNS of people aged over 64 years found that dietary haem $\mathrm{Fe}$ intake was positively associated with serum ferritin of the women but not in men ${ }^{30}$. Cade also reported that there was a strong positive association between serum ferritin and haem $\mathrm{Fe}$, but not total $\mathrm{Fe}$ or non-haem $\mathrm{Fe}$, and there was an effect of genotype that primarily occurred after menopause ${ }^{31}$.

With regard to the NSHD cohort, at age 53 years, the reduction in haem intake may be advantageous as there have been reported associations between moderate increases in body $\mathrm{Fe}$ stores and/or haem $\mathrm{Fe}$ intake of the elderly and risk for some age-related chronic diseases. An increased risk of myocardial infarction among men with higher intakes of haem $\mathrm{Fe}$, which itself was positively associated with higher Fe stores, was reported from the USA ${ }^{32}$. In the Netherlands, CHD was found to be linked with high dietary haem $\mathrm{Fe}$ intake in women ${ }^{33}$. These women had very high haem Fe intakes; a mean of $1.81 \mathrm{mg} / \mathrm{d}$, which was much higher than the $0.52 \mathrm{mg} / \mathrm{d}$ of the NSHD women. A positive association has also been found between haem Fe intake and the risk of type II diabetes ${ }^{34,35}$, although the authors qualify their findings by admitting that they were unable to determine whether the association was due to haem $\mathrm{Fe}$ or to other components of red meat.

There are reports that the association between colon cancer and red meat consumption is not due to the fat or protein content of meat but its haem Fe content. Haem Fe was shown to increase epithelial proliferation and colonic cytotoxicity in rats ${ }^{36}$, and in studies on rats and human subjects haem $\mathrm{Fe}$ intake was associated with markers for colon cancer risk ${ }^{37,38}$.

An elevated risk of colon cancer with increasing intake of haem $\mathrm{Fe}$ was suggested by data from the Netherlands Cohort $^{39}$ and the Iowa Women's Health Study ${ }^{40}$.

Finally, there have been reports of associations between $\mathrm{Fe}$ stores, ageing and neurodegenerative disorders. There are mechanisms within the brain to store and regulate the availability of Fe that is vital to its function but there is evidence that in some neurodegenerative disorders there is an excess accumulation of $\mathrm{Fe}$ at specific sites that suggests that the homeostatic mechanisms are disturbed ${ }^{41-43}$. In Parkinson's disease, the pigment neuromelanin in the substantia nigra has a high Fe binding capacity ${ }^{44}$.

Compared with other haem Fe intakes reported, $1.81 \mathrm{mg} / \mathrm{d}$ (women) in the Netherlands ${ }^{33}, 1.13 \mathrm{mg} / \mathrm{d}$ in Italy $^{45}$ and $1.27 \mathrm{mg} / \mathrm{d}$ (men) in the USA ${ }^{34}$, the haem Fe intake of the NSHD cohort, 0.78 (men) and 0.52 (women) $\mathrm{mg} / \mathrm{d}$, was low but agreed with that reported for the UK nationally; 0.9 and $0.6 \mathrm{mg} / \mathrm{d}^{2}$. As described earlier, these higher intakes may have been due to differences in estimation of haem $\mathrm{Fe}$ in foods in different countries and this emphasises the need for further analytical work to establish an accurate database of haem $\mathrm{Fe}$ content of British foods. However, Fe intake is not an indicator of status and until a formula is calculated from the whole diet on a meal-by-meal basis, which takes into account both the enhancers and inhibitors of $\mathrm{Fe}$ absorption, we cannot judge how much of the dietary Fe was actually available to the NSHD subjects. The health of the cohort is being followed as they age and further work is needed to establish whether they are at risk of over- or under-nutrition with regard to $\mathrm{Fe}$.

\section{References}

1. Ruston D, Hoare J, Henderson L, Gregory J, Bates C, Prentice A, Birch M, Swan G \& Farron M (2004) The National Diet and Nutrition Survey: Adults Aged 19-64 Years. Volume 4. Nutritional Status (Anthropometry and Blood Analytes) Blood Pressure and Physical Activity. London: The Stationery Office. 
2. Henderson L, Irving K, Bates CJ, Prentice A, Perks J, Swan G \& Farron M (2003) The National Diet and Nutrition Survey: Adults Aged 19-64 Years. Volume 3. Vitamin and Mineral Intake and Urinary Analytes. London: The Stationery Office.

3. Hallberg L (1982) Iron requirements and bioavailability of dietary Fe. Experientia Suppl 44, 223-244.

4. Hallberg L, Hulten L \& Gramatkovski E (1997) Iron absorption from the whole diet in men: how effective is the regulation of $\mathrm{Fe}$ absorption? Am J Clin Nutr 66, 347-356.

5. Department for Environment, Food and Rural Affairs (2001) National Food Survey 2000: Annual Report on Food Expenditure, Consumption and Nutrient Intakes. London: The Stationery Office.

6. Norat T, Bingham S, Ferrari P, et al. (2005) Meat, fish, and colorectal cancer risk: the European Prospective Investigation into cancer and nutrition. J Natl Cancer Inst 97, 906-916.

7. Hu FB, Stampfer MJ, Manson JE, Ascherio A, Colditz GA, Speizer FE, Hennekens CH \& Willett WC (1999) Dietary saturated fats and their food sources in relation to the risk of coronary heart disease in women. Am J Clin Nutr 70, $1001-1008$

8. Prynne CJ, Paul AA, Mishra GD, Greenberg DC \& Wadsworth MEJ (2005) Changes in intake of key nutrients over 17 years during adult life of a British birth cohort. $\mathrm{Br} \mathrm{J}$ Nutr 94, 368-376.

9. Wadsworth ME, Butterworth SL, Hardy RJ, Kuh DJ, Richards M, Langenberg C, Hilder WS \& Connor M (2003) The life course prospective design: an example of benefits and problems associated with study longevity. Soc Sci Med 57, 2193-2205.

10. Price GM, Paul AA, Key FB, Harter AC, Cole TJ, Day KC \& Wadsworth MEJ (1995) Measurement of diet in a large national survey: comparison of computerised and manual coding in household measures. J Hum Nutr Diet 8, 417-428.

11. Food Standards Agency (2002) McCance and Widdowson's The Composition of Foods, Sixth summary edition, Cambridge: Royal Society of Chemistry.

12. Holland B, Unwin I \& Buss DH (1988) Cereals and Cereal Products: Third supplement to McCance and Widdowson's The Composition of Foods. Nottingham: Royal Society of Chemistry and Ministry of Agriculture, Fisheries and Food.

13. Holland B, Unwin ID \& Buss DH (1989) Milk and Milk Products: Fourth Supplement to McCance and Widdowson's The Composition of Foods. Cambridge: Royal Society of Chemistry and Ministry of Agriculture, Fisheries and Food

14. Paul AA \& Southgate DAT (1978) McCance and Widdowson's The Composition of Foods, 4th ed. London: HMSO.

15. Chan W, Brown J, Church S \& Buss D (1996) Meat Products and Dishes. Sixth supplement to McCance and Widdowson's The Composition of Foods. Bath: Royal Society of Chemistry and Ministry of Agriculture, Fisheries and Food.

16. Chan W, Brown J, Lee SM \& Buss DH (1995) Meat, Poultry and Game. Fifth supplement to McCance and Widdowson's The Composition of Foods. Bath: Royal Society of Chemistry and Ministry of Agriculture, Fisheries and Food.

17. Smithers G (1993) MAFF's Nutrient databank. Nutr and Food Sci 92, 16-19.

18. Kinnear PR \& Gray CD (2000) SPSS for Windows Made Simple. Release 10. Psychology Press, Taylor \& Francis Group.

19. Cade J, Calvert C \& Barrett J (1998) How could the BSE crisis affect nutrient intake? Comparison of beef and non-beef eating meat eaters from the UK Women's Cohort Study. Europ J Clin Nutr 52, 151-152.

20. Monsen ER, Hallberg L, Layrisse M, Hegsted DM, Cook JD, Mertz W \& Finch CA (1978) Estimation of available dietary Fe. Am J Clin Nutr 31, 134-141.
21. Lombardi-Boccia G, Martinez-Dominguez B \& Aguzzi A (2002) Total heme and non-heme $\mathrm{Fe}$ in raw and cooked meats. J Fd Sci 67, 1738-1741.

22. Bull NL \& Buss DH (1980) Haem and non-haem Fe in British household diets. J Hum Nutr 34, 141-145.

23. Purchas RW \& Busboom JR (2005) The effect of production system and age on levels of Fe, taurine, carnosine, coenzyme $\mathrm{Q} 10$, and creatine in beef muscles and liver. Meat Science 70, 589-596.

24. Department for Environment Food and Rural Affairs, Beef Assurance Scheme (www.defra.gov.uk).

25. Ricketts MN (2004) Public health and the BSE epidemic. Curr Top Microbiol Immunol 284, 99-119.

26. Bradley R (1991) Bovine spongiform encephalopathy (BSE): the current situation and research. Europ J Epi 7, 532-544.

27. Gibson S \& Ashwell M (2003) The association between red and processed meat consumption and $\mathrm{Fe}$ intakes and status among British adults. Public Health Nutr 6, 341-350.

28. Department of Health (1991) Dietary Reference Values for Food Energy and Nutrients for the United Kingdom. London: HMSO.

29. Garry PJ, Hunt WC \& Baumgartner RN (2000) Effects of Fe intake on $\mathrm{Fe}$ stores in elderly men and women: longitudinal and cross-sectional results. J Am Coll Nutr 19, 262-269.

30. Doyle W, Crawley H, Robert H \& Bates CJ (1999) Iron deficiency in older people: interactions between food and nutrient intakes with biochemical measures of Fe; further analysis of the National Diet and Nutrition Survey of people aged 65 years and over. Eur J Clin Nutr 53, 552-559.

31. Cade JE, Moreton JA, O'Hara B, Greenwood DC, Moor J, Burley VJ, Kukalizch K, Bishop DT \& Worwood M (2005) Diet and genetic factors associated with $\mathrm{Fe}$ status in middleaged women. Am J Clin Nutr 82, 813-820.

32. Ascherio A, Willett WC, Rimm EB, Giovannucci EL \& Stampfer MJ (1994) Dietary Fe intake and risk of coronary disease among men. Circulation 89, 969-974.

33. Van der A DL, Peeters PH, Grobbee DE, Marx JJ \& Van der Schouw YT (2005) Dietary haem Fe and coronary heart disease in women. Europ Heart J 26, 257-262.

34. Jiang R, Ma J, Asherio A, Stampher MJ, Willett WC \& Hu FB (2004) Dietary $\mathrm{Fe}$ and blood donations in relation to risk of type 2 diabetes in men: a prospective cohort study. Am J Clin Nutr 79, 70-75.

35. Lee DH, Folsom AR \& Jacobs DRJ (2004) Dietary Fe intake and type 2 diabetes incidence in postmenopausal women: the Iowa Women's Health Study. Diabetologia 2, 185-194.

36. Sesink AL, Termont DS, Kleibeuker JH \& Van Der Meer R (2000) Red meat and colon cancer: Dietary haem, but not fat, has cytotoxic and hyperproliferative effects on rat colonic epithelium. Carcinogenesis 21, 1909-1915.

37. Pierre F, Peiro G, Tache S, Cross AJ, Bingham SA, Gasc N, Gottardi G, Corpet DE \& Gueraud F (2006) New marker of colon cancer risk associated with heme intake: 1,4-dihydroxynonane mercapturic acid. Cancer Epidemiol Biomarkers Prev 15, 2274-2279.

38. Cross AJ, Pollock JR \& Bingham SA (2003) Haem, not protein or inorganic $\mathrm{Fe}$, is responsible for endogenous intestinal $\mathrm{N}$-nitrosation arising from red meat. Cancer Res 63, $2358-2360$

39. Balder HF, Vogel J, Jansen MC, Weijenberg MP, van den Brandt PA, Westenbrink S, van der Meer R \& Goldbohm RA (2006) Heme and chlorophyll intake and risk of colorectal cancer in the Netherlands cohort study. Cancer Epidemiol Biomarkers Prev 15, 717-725.

40. Lee DH, Anderson KE, Harnack LJ, Folsom AR \& Jacobs DR Jr (2004) Heme Fe, zinc, alcohol consumption, and colon cancer: Iowa Women's Health Study. J Natl Cancer Inst 96, 403-407. 
41. Thompson KJ, Shoham S \& Connor JR (2001) Iron and neurodegenerative disorders. Brain Res Bull 55, 155-164.

42. Double KL, Gerlach M, Youdim MB \& Riederer P (2000) Impaired $\mathrm{Fe}$ homeostasis in Parkinson's disease. J Neural Transm Suppl 37-58.

43. Zecca L, Youdim MB, Riederer P, Connor JR \& Crichton RR (2004) Iron, brain ageing and neurodegenerative disorders. Nat Rev Neurosci 5, 863-873.
44. Double KL, Gerlach M, Schunemann V, Trautwein AX, Zecca L, Gallorini M, Youdim MB, Riederer P \& Ben-Shachar D (2003) Iron-binding characteristics of neuromelanin of the human substantia nigra. Biochem Pharmacol 66, 489-494.

45. Lombardi-Boccia G, Lanzi S, Lucarini M \& Di Lullo G (2004) Meat and meat products consumption in Italy: contribution to trace elements, heme $\mathrm{Fe}$ and selected B vitamins supply. Int $J$ Vitam Nutr Res 74, 247-251. 